\title{
PENERAPAN MODEL MIND MAPPING (PETA PIKIRAN) TERHADAP \\ KETERAMPILAN MENULIS TEKS EKSPOSISI SISWA KELAS \\ X IPS SMA KRISTEN HOSANA MEDAN 2018/2019 \\ Oleh
}

\author{
Faisan Sarumaha \\ Dian Syahfitri, S.S., M.Hum \\ SMA Kristen Hosana Medan, Universitas Prima Indonesia Medan \\ Jurusan Pendidikan Bahasa dan Sastra Indonesia \\ Fakultas Keguruan dan Ilmu Pendidikan \\ Medan, Indonesia \\ e-mail:sarumaha.faisan@yahoo.com
}

\begin{abstract}
ABSTRAK
Penelitian ini bertujuan untukmendeskripsikan peningkatan hasil belajar siswa dengan menggunakan model mind mapping (peta pikiran) dalam keterampilan menulis teks eksposisi siswa kelas X IPS SMA Kristen Hosana Medan 2018/2019. Subjek dalam penelitian ini adalah guru bahasa Indonesia dan siswa kelas X IPS SMA Kristen Hosana Medan yang berjumlah 25 orang. Objek penelitian ini adalah peningkatan hasil belajar siswa dalam penggunaan model mind mapping (peta pikiran).Metode pengumpulan data yang digunakan dalam penelitian ini adalah metode tes, observasi, wawancara, dan dokumentasi.Sedangkan, pendekatan penelitian ini adalah menggunakan deskriptif kualitatif dalam bentuk PTK. Hasil penelitian ini adalah adanya peningkatan hasil pembelajaran menulis teks eksposisi menggunakan model mind mapping (peta pikiran) dari dua siklus yang telah dilakukan dengan rincian hasil peningkatan bahwa di siklus I memperoleh KKK 64\% yang tuntas dan meningkat pada siklus II dengan memperoleh KKK sebesar $92 \%$ yang tuntas.
\end{abstract}

\section{Kata Kunci: Mind Mapping, Menulis Teks Ekposisi, PTK}

\section{PENDAHULUAN}

Bahasa Indonesia mempunyai kedudukan yang sangat penting dalam kehidupan bangsa dan negara Indonesia. Kedudukan bahasa dan fungsi bahasa Indonesia sebagai bahasa nasional berfungsi sebagai1) lambang kebanggaan nasional, 2) lambang identitas nasional, 3) alat pemersatu berbagai masyarakat yang mempunyai latar belakang, agama, suku, budaya, dan ras yang berbeda, 4) alat penghubung antar daerah.

Tujuan pembelajaran disajikan dalam komponen kebahasaan, komponen pemahaman, komponen 
penggunaan secara terpadu. Dalam kurikulum tiga belas (K13), terdapat empat ketarampilan berbahasa diantaranya: keterampilan menyimak, keterampilan berbicara, keterampilan membaca, dan keterampilan menulis. Diantara keempat keterampilan tersebut, keterampilan menulis merupakan salah satu Kompetensi Dasar dalam Standar Kompetensi.Keterampilan menulis merupakan keterampilan yang bersifat produktif, artinya keterampilan menulis merupakan keterampilan yang menghasilkan yaitu menghasilkan tulissan.Menurut Leo (2017: 1) bahwa menulis adalah sebuah kegiatan menuangkan pikiran kedalam bentuk simbo-simbol tulisan. Menurut Dalman (2015: 3) menulis merupakan sebuah proses kreatif menuangkan gagasan dalam bentuk bahasa tulis.

Menurut Jauhari (2013: 16) menulis merupakan salah satu aspek keterampilan berbahasa ketiga.Tarigan (dalam Dalman, 2015: 4)mengatakan bahawa menulis ialah melukiskan lambing-lambang grafis yang menghasilkan suatu bahasa.Menurut Tarigan (1994: 3) bahwa menulis ialah suatu keterampilan berbahasa digunakan berkomunikasi secara tidak
langsung.Dalam menulis, hal yang dikembangkan adalah menulis teks eksposisi.Eksposisi adalah jenis tulisan yang ditujukan untuk menuangkan ide, menjelaskan fakta, dan opini.Menurut Kosasih (2017: 23) bahwa teks eksposisi adalah teks memberitakan dengan analisis dan penjelasan.Dalman (2015: 120) teks eksposisi adalah karangan yang menjelaskan pendapat atau gagasan.Menurut Keraf bahawa eksposisi adalah bentuk wacana yang berusaha menguraikan suatu objek. Menutur Akhadiah, dkk bahwa karangan eksposisi adalah suatu corak yang menerangkan suatu hal yang memperluas pandangan dan wawasan, (dalam Sitinjak, 2018: 38).

Berbagai hal terkait dengan kegiatan menulis teks eksposisi memungkinkan terjadinya hambatan bagi siswa dalam upaya menulis teks eksposisi.Hal ini yang mendasari peneliti memilih variabel penelitian ini.Dikarenakan rendahnya kemampuan siswa dalam pembelajaran menulis teks eksposisi. Siswa kurang aktif dalam kegiatan menulis, siswa kurang bisa menuangkan ide-idenya, siswa masih belum bisa menyiapkan konsep karangan tulisannya, dan kurangnya variasi model pembelajaran dalam 
kegiatan menulis teks eksposisi. Hal tersebutlah yang menjadi kendala utama siswa di kelas X IPS dalam kegiatan menulis teks eksposisi. Permasalahan yang dihadapi oleh siswa dalam pembelajaran terkesan sangat sulit untuk dapat diatasi oleh guru.

Berdasarkan gambaran tersebut, peneliti tertarik mencoba menerapkan model pembelajaran Mind Mapping dalam pembelajaran menulis teks eksposisi. Menurut Kurniasih dan Sani (2016: 53) bahwa mind mapping merupakan sebauah peta rute yang menggunakan ingatan membuat kita bisa menyusun fakta dan pikiran sedemikian rupa. Menurut Zubaedi (2017: 155) mind mapping adalah sebuah cara menggambarkan bagaimana otak bisa mencari dan menemukan ide dalam jumlah besar dengan waktu yang singkat. Fathurrohman (2015: 206) menjelaskan mind mapping diartikan sebagai suatu cara untuk mengorganisasikan konsep dan ide. Menurut Saleh bahwa mind mapping adalah proses pembuatan diagram yang digunakan untuk menggambarkan sebuah ide atau gagasan utama dalam materi pembelajaran. Suyatno bahwa mind mapping adalah teknik yang mempelajari suatu konsep didasarkan cara kerja otak manusia. Mind map adalah teknik pembelajaran kreatif dan efisien, (dalam Agustawan, dkk 2014: 4).

Selain itu, dalam belajar teknik mind mapping juga akan membantu siswa dalam memahami dan menyerap informasi dengan cepat sehingga daya ingat siswa lebih optimal. Dengan menggunakan model mind mapping, siswa akan lebih tertarik untuk belajar, kemudian akan dengan mudah mengingat dan memahami materi sehingga mampu untuk menulis sebuah teks eksposisi. Berdasarkan uraian dan pemikiran tersebut, peneliti mencoba melakukan sebuah penelitian yang berjudul "Penerapan ModelMind Mapping(Peta Pikiran) Terhadap Keterampilan Menulis Teks Eksposisi Siswa Kelas X IPS SMA Kristen Hosana Medan 2018/2019".Berdasarkan hal tersebut, penelitian ini membahas tentang peningkatan hasil belajar siswa dengan menggunakan model mind mapping (peta pikiran) terhadap keterampilan menulis teks eksposisi siswa kelas $\mathrm{X}$ IPS SMA Kristen Hosana Medan 2018/2019. Sejalan dengan masalah itu, penelitian ini bertujuan untuk 
mengetahui peningkatan hasil belajar siswa dengan menggunakan model mind mapping (peta pikiran) terhadap keterampilan menulis teks eksposisi siswa kelas X IPS SMA Kristen Hosana Medan 2018/2019.

\section{METODE PENELITIAN}

Penelitian ini menggunakan rancangan penelitian tindakan kelas (classroom action research) dilakukan dalam bentuk siklus. Dalam penelitian ini, peneliti merancang metode penelitian yang meliputi: perencanaan tindakan, pelaksanaan tindakan, observasi, dan refleksi. Subjek penelitian ini adalah siswa kelas X IPS SMA Kristen Hosana Medan yang berjumlah 25 siswa, dengan 13 siswa laki-laki dan 12 siswa perempuan. Objekpenelitian ini adalahpeningkatan hasil belajar mengajar dalam penggunaan model mind mapping (peta pikiran) dalam meningkatkan keterampilan menulis teks eksposisi siswa kelas X IPS SMA Kristen Hosana Medan 2018/2019. Metode pengumpulan data yang digunakan dalam penelitian ini adalah metode tes, observasi,wawancara, dan dokumentasi. Data dianalisis dengan menggunakan teknik deskriptif kualitatif.
Penelitian tindakan kelas (PTK) ini mengandung data kualitatif yaitu berupa data hasil dan aktivitas belajar mengajar siswa selama dalam proses menulis teks eksposisi dengan menggunakan model mind mapping (peta pikiran). Sumber data diperoleh dari tempat penelitian yakni di kelas $\mathrm{X}$ IPS SMA Kristen Hosana Medan. Setelah data terkumpul, selanjutnya akan dianalisis dengan menggunakan analisis data secara deskriptif kualitatif. Analisis deskriptif kualitatif merupakan teknik analisis data yang menginterprestasikan sebuah fenomena secara umum untuk dicari kesimpulannya.

Kriteria keberhasilan belajar menulis teks eksposisi ditunjukkan dengan adanya keberhasilan pemerolehan skor rata-rata kelas pada kategori tuntas atau $75 \%$ dari jumlah siswa yang memperoleh skor 75.Skor tersebut telah sesuai dengan standar kriteria ketuntasan minimal (KKM) pelajaran Bahasa Indonesia yang ditetapkan di SMA Kristen Hosana Medan.Dengan tercapainya kriteria keberhasilan yang telah ditentukan tersebut, penelitian ini dapat dihentikan. Siklus tindakan yang mampu mencapai kriteria keberhasilan ataupun 
ketercapaian KKM dianggap sebagai tindakan terbaik yang memenuhi kriteria keberhasilan.

\section{HASIL DAN PEMBAHASAN}

Temuan yang menyangkut peningkatan kemampuan menulis teks eksposisi dengan penerapan model mind mapping (peta pikiran) yaitu: Proses pembelajaran pada penelitian ini yang sudah dilaksanakan peneliti dengan menerapkan model mind mapping untuk memperbaiki kemampuan menulis teks eksposisi siswa kelas $\mathrm{X}$ IPS SMA Kristen Hosana Medan telah mendapatkan hasil peneltian dengan menyatakan bahwa kemampuan siswa dalam menulis teks eksposisiyang telah diamati dapat meningkat. Hasil penelitian ini terlihat dari penilaian tes yang diberikan kepada siswa untuk dikerjakan di setiap tahap-tahap kegiatan pembelajaran yang telah dilakukan penelitian yaitu siklus I dan siklus II.
Pelaksanaan pembelajaran menulis teks eksposisi pada siklus I diberikan tes awal untuk mengetahui kemampuan awal pemahaman siswa terhadap materi pembelajaran menulis teks eksposisi dengan menerapkan model mind mapping (peta pikiran). Adapun hasilnya bahwa 16 siswa atau $64 \%$ siswa yang tuntas mendaptkan standar nilai KKM 75. Sedangkan siswa yang belum tuntas mendapatkan nilai KKM 75 ada 9 siswa atau $36 \%$.Dari penilaian hasil data tersebut dinyatakan bahwa keterampilan menulis teks eksposisi siswa belum memuaskan karena belum sesuai dengan keberhasilan target KKM 75 dan kriteria ketuntasan klasikal (KKK) yaitu $75 \%$ dari jumlah siswa.Adapun rangkuman hasil data pelaksanaan observasi pada siklus I yang berupa hasil penilaian tes awal keterampilan menulis teks eksposisi terangkum dalam tabel 1 berikut.

Tabel 1 Kriteria Tingkat Keberhasilan Hasil Belajar Pada Siklus I

\begin{tabular}{|c|c|c|c|c|}
\hline Kategori & Rentang Nilai & Banyak Siswa & $\begin{array}{c}\text { Nilai } \\
\text { Persentase } \\
\text { KKK }\end{array}$ & Keterangan \\
\hline Sangat tinggi & $85-100$ & 7 & $28 \%$ & Tuntas \\
\hline Tinggi & $75-84$ & 9 & $36 \%$ & Tuntas \\
\hline
\end{tabular}




\begin{tabular}{|c|c|c|c|c|}
\hline Sedang & $65-74$ & 5 & $20 \%$ & Tidak Tuntas \\
\hline Rendah & $55-64$ & 3 & $12 \%$ & Tidak Tuntas \\
\hline Sangat rendah & $40-54$ & 1 & $4 \%$ & Tidak Tuntas \\
\hline \multicolumn{2}{|c|}{ Jumlah } & 25 & $100 \%$ & \\
\hline \multicolumn{3}{|c|}{ Persentase Ketuntasan Klasikal = 16 : 25 x 100\% $=\mathbf{6 4 \%}$} \\
\hline
\end{tabular}

Melihat hasil dari siklus I tersebut perlu dilakukan perbaikan dari permasalahan yang ada sehingga peneliti mengidentifikasi dan merencanakan perbaikannya denagan melakukan tindakan proses pembelajaran di siklus II agar pembelajaran menulis teks eksposisi siswa dapat meningkat sesuai nilai KKM pelajaran Bahasa Indonesia yaitu 75. Proses pembelajaran siklus II pun masih menggunakan model mind mapping (peta pikiran). Adapun hasil penelitian yang peneliti peroleh nilai siswa di siklus II yang mendapatkan standar nilai KKM 75 mencapai 23 siswa atau 94\% yang sudah tuntas. Sedangkan, siswa yang belum tuntas mendapatkan nilai KKM 75 adalah 2 siswa atau $8 \%$ siswa.Adapun rangkuman hasil data pelaksanaan penelitian pada siklus II yang berupa hasil penilaian tes keterampilan menulis teks eksposisi terangkum dalam tabel 2 berikut.

\section{Tabel 2 Kriteria Tingkat Kberhasilan Hasil Belajar Pada Siklus II}

\begin{tabular}{|c|c|c|c|c|}
\hline Kategori & Rentang Nilai & Banyak Siswa & $\begin{array}{c}\text { Nilai } \\
\text { Persentase } \\
\text { KKK }\end{array}$ & keterangan \\
\hline Sangat tinggi & $85-100$ & 11 & $44 \%$ & Tuntas \\
\hline Tinggi & $75-84$ & 12 & $48 \%$ & Tuntas \\
\hline Sedang & $65-74$ & 2 & $8 \%$ & Tidak Tuntas \\
\hline Rendah & $55-64$ & - & - & Tidak Tuntas \\
\hline Sangat rendah & $40-54$ & - & - & Tidak Tuntas \\
\hline \multicolumn{2}{|c|}{ Jumlah } & 25 & $100 \%$ & \\
\hline \multicolumn{5}{|c|}{ Persentase Ketuntasan Klasikal $=23: 25$ x $100 \%=92 \%$} \\
\hline
\end{tabular}


Pada proses pembelajaran siklus

I dan siklus II yang telah dilaksanakan dengan menerapkan model mind mapping (peta pikiran) perbaikan dari kondisi awal siswa agar dapat mencapai target KKM 75 dan KKK siswa $\geq 75 \%$. Adapun hasilnya pada kegiatan pembelajaran siklus I yang peneliti lakukan di kelas X IPS siswa yang tuntas mendapatkan standar KKM 75 hanya 16 siswa 64\%. Sedangkan, siswa yang belum tuntas mendapatkan nilai nilai 75 ada 9 siswa 36\%.Pada prosess siklus I indicator keberhasilan pada penilaian KKK siswa belum sesuai atau melampaui $\geq 75 \%$ sehingga dapat disimpulkan belum tercapai.

Dalam hal tersebut, peneliti pun melakukan perlakuan untuk memperbaiki situasi pembelajaran menulis teks eksposisi yang terjadi di kelas $\mathrm{X}$ IPS dengan melakukan tindakan pembelajaran yaitu memperbaiki penerapan model mind

Tabel 3 Rekapitulasi Peningkatan Hasil Nilai Tes Siklus I dan Siklus II Keterampilan Menulis Teks Eksposisi

\begin{tabular}{|c|c|c|}
\hline Rentang Nilai & Siklus & Siklus \\
& I & II \\
\hline $\mathbf{8 5 - 1 0 0}$ & 7 & 11 \\
\hline $\mathbf{7 5 - 8 4}$ & 9 & 2 \\
\hline $\mathbf{6 5 - 7 4}$ & 5 & 12 \\
\hline
\end{tabular}

mapping dalam menulis teks eksposisi yang dilaksanakan pada siklus II. Dari kegiatan pembelajaran tersebut sudah dilaksanakan dan hasil pelaksanaanya telah ditemukan jawabannya bahwa penerapan model mind mapping (peta pikiran) dapat meningkatkan menulis teks eksposisi pada siswa kelas X IPS SMA Kristen Hosana Medan. Adapun bukti data peningkatan nilai hasil pembelajaran menulis teks eksposisi siswa pada siklus I dan siklus II dari tes yang telah diberikan pada akhir proses pembelajaran di tiap siklusnya dapat dilihat dalam rangkuman hasil penilaian keterampilan menulis teks eksposisi pada tabel 3 berikut. 


\begin{tabular}{|c|c|c|}
\hline $\mathbf{5 5 - 6 4}$ & 3 & - \\
\hline $\mathbf{4 0 - 5 4}$ & 1 & 25 \\
\hline$\sum$ & 25 & 95 \\
\hline Nilai Tertinggi & 90 & 70 \\
\hline Nilai Terendah & 50 & 92 \\
\hline Persentase Ketuntasan & 64 & 8 \\
Klasikal & $\%$ & $\%$ \\
\hline Persentase Yang Tidak & 36 & $\%$ \\
\hline
\end{tabular}

Untuk memberikan gambaran yang jelas atas pencapaian hasil penelitian yang telah meningkat pada siklus I dan siklus II dari hasil tes dalam pembelajaran menulis teks eksposisi dapat dilihat melalui diagram 1 sebagai berikut.

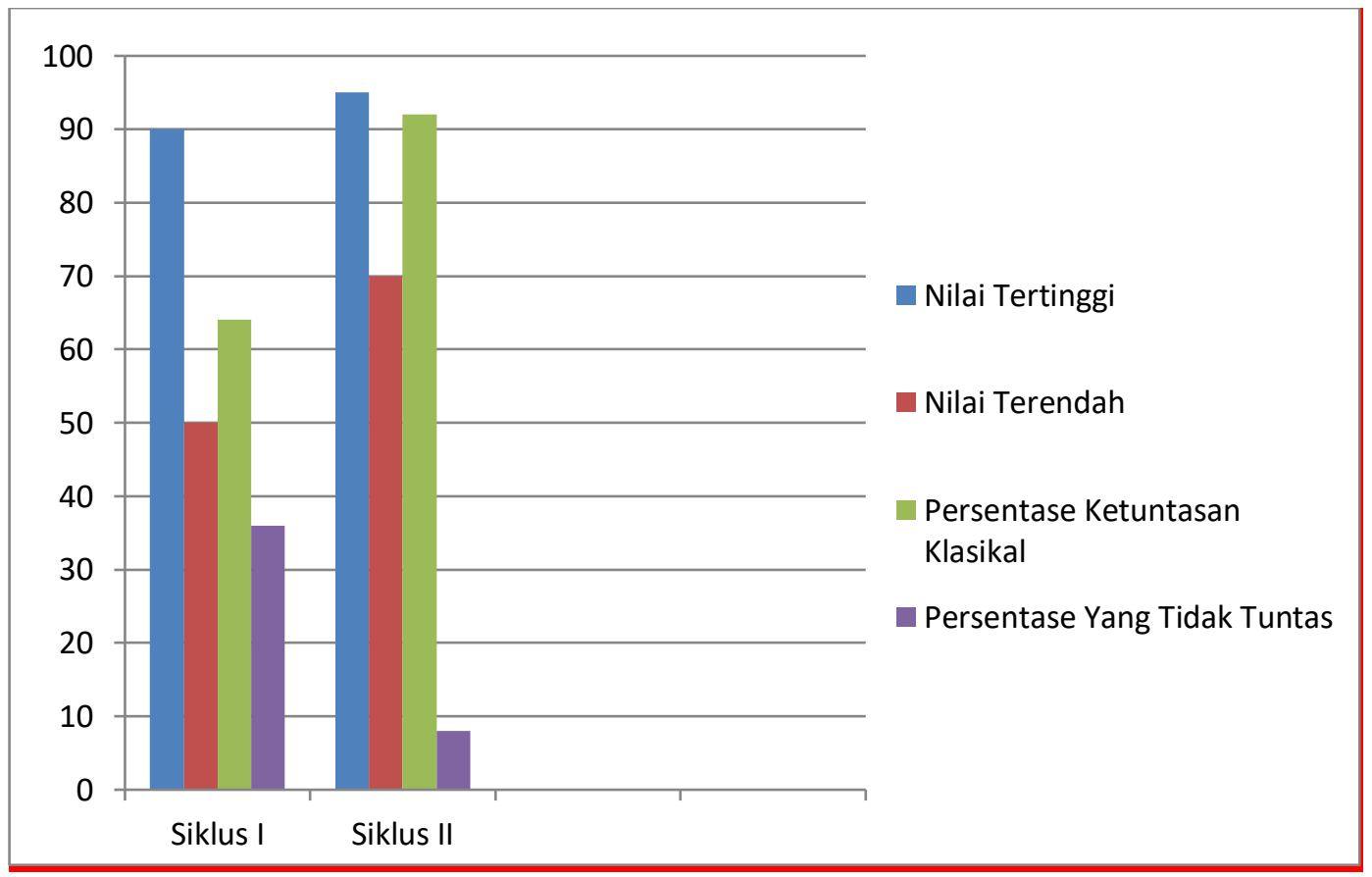

Diagram 1Rekapitulasi Peningkatan Hasil Tes Siklus I dan Siklus II Keterampilan Menulis Teks Ekpsosisi Siswa Kelas X IPS

SMA Kristen Hosana Medan 2018/2019

Untuk memberikan gambaran yang jelas atas pencapaian hasil penelitian yang telah meningkat pada siklus I dan siklus II dari hasil tes dalam pembelajaran keterampilan menulis teks eksposisi dapat dilihat melalui tabel 4 sebagai berikut. 
Tabel 4 Hasil Peningkatan Nilai Tes Siklus I dan Siklus II Menulis Teks Eksposisi

\begin{tabular}{|c|c|c|c|c|}
\hline Siklus & $\begin{array}{c}\text { Jumlah } \\
\text { Siswa }\end{array}$ & $\begin{array}{c}\text { Tuntas } \\
\text { KKM }\end{array}$ & $\begin{array}{c}\text { Belum } \\
\text { tuntas KKM }\end{array}$ & $\begin{array}{c}\text { Kriteria } \\
\text { Ketuntasan } \\
\text { Klasikal (\%) }\end{array}$ \\
\hline Siklus I & 25 & 16 & 9 & $64 \%$ \\
\hline Siklus II & 25 & 23 & 2 & $92 \%$ \\
\hline \multicolumn{5}{|c|}{ PENINGKATAN } \\
\hline
\end{tabular}

Oleh karena itu, proses pembelajaran Bahasa Indonesia yang menerapkan model pembelajaran mind mapping (peta pikiran) dari siklus I dan siklus II meningkat sebesar $28 \%$ pada pembelajaran menulis teks eksposisi siswa kelas X IPS SMA Kristen Hosana Medan 2018/2019.

Dari hasil yang telah diperoleh tersebut, pemilihan model dalam proses belajar mengajar yang menarik akan menentukan berhasil tidaknya tujuan yang ingin dicapai dalam pembelajaran tersebut. Guru harus mampu memilih dan menerapkan model secara efektif yang berdampak pada hasil akhirnya siswa mampu menulis teks eksposisi. Tahap tindakan yang telah dilakukan dalam penelitian ini adalah menerapkan model mind mapping untuk meningkatkan keterampilan menulis teks eksposisi siswa dalam menulis teks eksposisi.
Model pembelajaran pada proses pembelajaran menulis teks eksposisi tekah dilaksanakan melalui dua siklus. Dalam setiap siklus meliputi beberapa tahap yaitu, tahap perencanaan, tahap tindakan, tahap observasi, dan tahap refleksi.Berdasarkan hasil analisis data dari siklus I dan siklus II, pada siklus I dilakukan tindakan pembelajaran keterampilan menulis teks eksposisi dengan menerapkan model mind mapping (peta pikiran) belum berhasil karena belum memenuhi kriteria ketuntasan klasikal yaitu $75 \%$. Berdasarkan hasil pengamatan peneliti dan guru dari lembar observasi kegiatan guru dan kegiatan siswa pada siklus I terdapat beberapa aspek permasalahan yang telah diuraikan di tahap observasi sebelumnya.Kemudian direncanakanlah proses perlakuan perbaikan dalam suatu tindakan di siklus selanjutnya. 
Pada kegiatan pembelajaran siswa saat menulis teks eksposisi dengan menggunakan model mind mapping di siklus I hanya mencapai 64\%. Hal ini karena masih banyak siswa yang tidak mengikuti instruksi peneliti untuk mempelajari ulang materi pembelajaran yang telah disampaikan, tidak semua siswa dapat berpartisipasi, dan siswa belum terbiasa dalam memberikan pendapat masing-masing pada proses pembelajaran dengan baik dan benar sehingga masih ada siswa yang tidak memperdulikan saat disuruh memberi pendapat.

Pada proses pembelajaran di siklus II yang masih menerapkan model mind mapping mengalami peningkatan. Hasil pembelajaran mendapat ketuntasan klasikal mencapai 92\% yang dapat dinyatakan memiliki tingkat penguasaan keterampilan menulis berkategori "tinggi". Hal ini karena sudah banyak siswa yang mau mengikuti instruksi dari peneliti dalam proses pembelajaran keterampilan menulis teks eksposisi. Siswa sudah mampu berpendapat dan membuat konsep sesuai ide pikiran mereka dalam pembelajaran dengan menggunakan dengan menggunakan model mind mapping (peta pikiran).
Maka dalam penelitian ini, peneliti menyatakan bahwa proses pembelajaran dalam menerapkan model mind mapping (peta pikiran) untuk meningkatkan keterampilan menulis teks eksposisi siswa kelas X IPS SMA Kristen Hosana Medan sudah berjalan dengan baik dan lancar. Terlihat dari hasil penilaian di siklus I dan siklus II meningkat sesuai dengan Kriteria Ketuntasan Minimal (KKM) 75 dan nilai persentase Ketuntasan Klasikal Siswa yaitu $\geq 75 \%$.Dengan demikian, dapat disimpulkan bahwa penerapan model mind mapping (peta pikiran) dapat meningkatkan keterampilan menulis teks eksposisi siswa kelas $\mathrm{X}$ IPS SMA Kristen Hosana Medan 2018/2019.

\section{PENUTUP}

Berdasarkan hasil penelitian yang telah diuraikan pada bab IV, maka dapat disimpulkan bahwa peningkatan hasil pembelajaran keterampilan menulis teks eksposisi dengan menerapkan model mind mapping (peta pikiran) telah meningkat. Terbukti dari hasil penelitian siklus I persentase ketuntasan klasikal yaitu $64 \%$ dan meningkat kembali pada siklus II yaitu 92\% dengan selisih peningkatan sebesar 28\%. Maka, model mind 
mapping (peta pikiran) pada bidang studi Bahasa Indonesia dengan sub pokok pembahasan materi pembelajaran menulis sangat berperan penting untuk meningkatkan keterampilan menulis teks eksposisi siswa dan mampu memberikan motivasi dalam proses pembelajaran menulis teks eksposisi di kelas X IPS SMA Kristen Hosana Medan.

\section{DAFTAR PUSTAKA}

Agustawan, dkk. 2014. Penggunaan Teknik Mind Mapping Untuk meningkatkan Kemampuan Siswa Dalam Menentukan Fakta dan Opini Pada Tajuk Rencana Bali Post di Kelas XI IPA 2 SMA Negeri 1 Sawan. Jurnal Pend. Bahasa dan Sastra Indonesia UNDIKSHA, No. 1, Vol. 2, 1-12.

Aqib, Z dkk.2008. Penelitian Tindakan Kelas (PTK) untuk Guru SD, $S L B$, dan TK. Bandung: CV Yrama Widya.

Arikunto, S dkk. 2012. Penelitian Tindakan Kelas. Jakarta: Bumi Aksara.

Dalman, H. 2015. Keterampilan Menulis. Jakarta: PT Raja Grafindo Persada.
Fathurrohman, Muhammad. 2015. Model-Model Pembelajaran Inovatif (Alternatif Desain Pembelajaran yang Menyenangkan). Yogyakarta: AR-RUZZ MEDIA.

Jauhari, Heri. 2018. Terampil Mengarang. Bandung: Nuansa Cendekia.

Kosasih, E. 2017.Jenis-Jenis Teks. Bandung: PT Yrama Widya.

Kurniasih dan Sani.2016. Ragam Pengembangan Model Pembelajaran.PT Kata Pena.

Leo, Sutanto. 2017. Mencerahkan Bakat Menulis. Jakarta: PT Gramedia Pustaka Utama.

Sugiyono. 2017. Metode Penelitian, Kuantitatif, Kualitatif, dan $R \& D$.

Tarigan, H.G. 2008.Menulis (Sebagai Suatu Keterampilan Berbahasa). Bandung: Angkasa Bandung.

Zubaedi. 2017. Strategi Taktis Pendidikan Karakter (Untuk PAUD dan Sekolah). Depok: PT RAJA GRAFINDO PERSADA. 